\title{
TINJAUAN TEORITIS
}

\section{SIMBIOSIS ZOOXANTHELLAE DAN KARANG SEBAGAI INDIKATOR KUALITAS EKOSISTEM TERUMBU KARANG}

\author{
Unstain NWJ Rembet ${ }^{1}$
}

\begin{abstract}
A symbiotic process between zooxanthellae and corals can support the adaptative factors in terms of natural vulnerability criteria. The proposed consideration are 1) the symbiosis between zooxanthellae and corals provides phenomenal contributions to coral evolutionary process and 2) the criteria used by Gomez and Yap have been merely based on live coral cover that is still becoming key tools for the evaluation of coral reef health status measure. These criteria have been weaker and weaker due to neglecting the feature of intra- and interspesific relationship in coral biota itself. Therefore, the use of zooxanthellae and coral symbiotic relationship is thought of being able to complete the coral reef quality evaluation since its information could address this relationship feature beside on the basis of response to environmental pressures.
\end{abstract}

Keywords : symbiotic, zooxanthellae, coral.

\section{ABSTRAK}

Proses simbiosis antara zooxanthellae dengan karang dapat memberikan suatu support terhadap faktor penyesuai dalam hal ini dari segi kriteria kerentanan alami. Pertimbangan yang diajukan adalah (1) simbiosis antara karang dengan zooxanthellae memberikan konstribusi fenomenal dalam proses evolusi karang dan (2) kriteria yang dipergunakan saat ini dari analisis Gomez dan Yap hanya didasarkan atas tutupan karang hidup yang sampai sekarang menjadi acuan bagi evaluasi tingkat status kesehatan terumbu. Kriteria tersebut dipandang mengalami kelemahan karena mengabaikan sifat hubungan intra dan ekstraspesifik dari biota karang itu sendiri. Atas dasar hal tersebut, maka penggunaan hubungan simbiosis zoxanthellae dan karang dipandang dapat melengkapi evâluasi kualitas terumbu karang karena informasinya dapat menjelaskan sifat hubungan intra dan ekstra spesifik, disamping atas dasar respon terhadap tekanan lingkungan.

Kata kunci : simbiosis, zooxanthellae, karang.

Laboratorium Pengelolaan Wilayah Pesisir Terpadu, FPIK UNSRAT

\section{PENDAHULUAN}

Terumbu karang (coral reef) merupakan ekosistem dasar laut yang penghuni utamanya berupa karang batu.
Berbagai spesies dan bentuk karang batu ini bersama-sama dengan makhluk hidup lainnya membentuk suatu ekosistem. Proses pembentukan terumbu karang memakan waktu yang lama dan selama itu pula ia dihuni oleh berbagai 
makhluk hidup lainnya. Arsitektur terumbu karang yang mengagumkan dibentuk oleh ribuan binatang kecil yang disebut dengan polip. Dalam bentuk sederhananya karang dapat terdiri dari satu polip saja yang mempunyai bentuk tubuh seperti tabung dengan mulut yang terletak di bagian atas dan dikelilingi oleh tentakel. Dalam banyak spesies karang, individu polip berkembang menjadi banyak individu yang disebut dengan koloni.

Menurut Veron (1995), terumbu karang adalah ekosistem khas daerah tropis dengan pusat penyebaran di wilayah Indo-pasifik. Terbatasnya penyebaran terumbu karang di perairan tropis dan secara latitudinal terbentang dari wilayah selatan Jepang sampai utara Australia dikontrol oleh faktor suhu dan sirkulasi permukaan (surface sirculation) air. Sementara itu, penyebaran secara longitudinal akan sangat dipengaruhi oleh adanya konektivitas berupa stepping stones. Kombinasi antara faktor lingkungan fisik (suhu dan. sirkulasi permukaan) dengan banyaknya jumlah stepping stones yang terdapat di wilayah indo-pasifik diperkirakan menjadi faktor yang sangat mendukung luasnya pemencaran terumbu karang di region tersebut. Kini, hampir 800 jenis karang telah dideskripsikan dan dari sejumlah karang yang ditemukan ini 600 jenis berada di Asia Tenggara khususnya di Indonesia dan Philipina (Burke et al. 2002) dân dengan pertimbangan luasan kawasannyâ sebesar 34\% (51\% kontribusi kawasan terumbu karang Indonesia) dari total luas kawasan terumbu karang di dunia maka secara biogeografi kawasan ini dinyatakan sebagai center of origin karang di dunia (veron, 1995).

Menurut Burke et al. (2002), ekosistem terumbu karang yang ada di wilayah Asia Tenggara merupakan yang paling terancam di dunia. Besarnya ketergantungan manusia terhadap sumberdaya laut di seluruh Asia Tenggara telah menyebabkan eksploitasi yang berlebih sehingga banyak terumbu karang yang terdegradasi, khususnya di dekat pusat kepadatan penduduk. Ancaman-ancaman terhadap terumbu karang termasuk penangkapan berlebih (over fishing), penangkapan ikan dengan metode yang merusak, sedimentasi dan pencemaran serta pembangunan pesisir. Selain itu meningkatnya suhu global (global warming) juga telah menyebabkan sumberdaya yang sangat vital ini dalam bahaya.

Secara umum terjadinya degradasi ekosistem terumbu karang ditimbulkan oleh dua penyebab utama, yaitu akibat kegiatan manusia (anthrophogenic causes) dan akibat alam (natural causes). Kegiatan manusia yang menyebabkan terjadinya degradasi terumbu karang antara lain: (1) penambangan dan pengambilan karang, (2) penangkapan ikan dengan menggunakan alat dan metode yang merusak, (3) penangkapan yang berlebih, (4) pencemaran perairan, (5) kegiatan pembangunan di wilayah pesisir, dan (6) kegiatan pembangunan di wilayah hulu. Sementara itu, degradasi terumbu karang yang disebabkan oleh alam antara lain oleh predator, pemanasan global, bencana alam seperti angin taufan, gempa tektonik, banjir dan tsunami serta bencana alam lainnya seperti El-Nino dan La-Nina (Westmacott et al. 2000; COREMAP, 2001; Burke et al., 2002).

Menurut Moosa dan Suharsono (1995), kegiatan merusak yang dilakukan oleh manusia akan lebih bersifat kronis, tidak bersifat sementara seperti halnya yang disebabkan oleh musibah alami. Karena terumbu karang mempunyai arti ekonomis yang cukup penting, maka kepulihannya dalam waktu yang lama merupakan suatu hal yang perlu dipikirkan.

\section{PROSES SIMBIOSIS ZOOXANTHELLAE DENGAN KARANG DAN PERAN FUNGSIONALNYA}

Sejak berabad-abad lalu hingga saat ini, karang (Scleractinia) dianggap sebagai batu atau tumbuhan walaupun sesungguhnya mereka merupakan hewan. Karang itu sendiri merupakan 
salah satu kelompok Coelenterata berbentuk polyp yaitu semacam bentuk tabung dengan mulut di bagian atas yang dikelilingi oleh tentakel. Secara morfologis, binatang ini berbentuk mirip satu dengan lainnya (species); pembedanya adalah keragaman rangka yang dibentukkannya. Oleh sebab itu, taksonomi karang didasarkan kepada rangka bentukannya. Karena kemampuannya ini maka karang bersifat menetap (sessile). Dengan tipe hidup ini membawa konsekuensi terhadap sifat konservatif dalam kehidupannya.

Salah satu sifat konservatif dari biota karang adalah adanya proses simbiosis dengan zooxanthellae. Proses terbentuknya simbiosis atau yang dikenal dengan endosimbiosis ini mengundang perdebatan sejak awalnya, yakni apakah terbentuknya endosimbiosis sejak anakan karang (planula) mulai dilepaskan oleh induknya atau melalui infeksi dari lepasan planula yang keluar tanpa pembekalan (Veron, 1995). Apabila teori pertama yang terjadi maka bagaimanapun juga awal evolusinya akan mengalami proses infeksi yang kemudian secara turun temurun mengalami proses pembekalan sebagaimana teori pertama diterima kebenarannya. Di sini tidak memperdebatkan Reduanya, namun lebih ditekankan bahwa pada kenyataannya terdapat endosimbiosis yang perannya besar dalam mekanisme kehidupan fungsional karang.

Pada kondisi awal evolusi dipahami bahwa simbiosis antara zooxanthellae dengan karang dalam ekosistem laut pada dasarnya merupakan suatu kejadian yang diawali oleh bertemunya zooxanthellae dengan karang dengan peluang yang tinggi oleh sebab karang hidup menetap dan zooxanthellae bersifat planktonik. Bertemunya keduanya mendapat peluang yang besar oleh adanya kondisi dinamik air laut. Oleh Perez (1982) dikemukakan bahwa proses recognisi dan pada akhirnya relokasi zooxanthellae pada karang merupakan fenomena respon biotik sebagai turunan dari aktivitas fisik dinamik air laut dan proses interkoneksitas kimiawi.
Dengan demikian peluang bertemunya keduanya sangat dimungkinkan terjadi di laut dengan dua pertimbangan tersebut.

Pada kebanyakan karang, relokasi zooxanthellae umumnya terdapat pada jaringan mesoglea dan gastrodermis baik di tentakel maupun mesentrinya (Veron, 1995). Untuk menempuh ini diperlukan tahapan-tahapan endosim biosis. Tahapan endosimbiosis tersebut oleh Lenhoff dan Muscatine (1990) diterangkan melalui 4 mekanisme, yaitu

1. Kontak dan Pengenalan (Recognition). Meskipun terdapat argumentasi bahwa infeksi zooxanthellae pada jaringan sêluler inangnya terjadi pada saat pelepasan planula, namun tahap ini diperlukan pada setiap perkembangan dari binatang karang. Proses ini merupakan proses transport yang tidak saja mencakup proses fisik akan tetapi juga biokomiawi.

2. Endocytosis. Merupakan proses pemasukan suatu algae selular ke dalam jaringan inang. Prosesnya dilakukan setelah mengalami tahap pengenalan dengan kecepatan dan jumlah yang bergantung kepada jenis dan kapasitas dari binatang karang.

3. Relokasi intraselluler dari simbiont, ini berkaitan dengan sistem endoskeleton dari binatang karang. Proses enzymatik yang membantu pelaksanaannya ditentukan oleh fluktuasi $\mathrm{pH}$ seluler.

4. Pertumbuhan dan regulasi kuantitasnya. Proses ini terjadi setelah relokasi dan berlangsung dengan bergantung kepada perubahan faktorfaktor eksternal penentu (khususnya faktor limiting) pertumbuhan. Pemutihan (bleaching) merupakan salah satu fenomena regulasi dari zooxanthellae dalam jaringan binatang karang.

Terapan fungsional simbiosis pertama-tama dapat ditinjau dari kaitannya dengan transfer nutrisi diantara keduanya. Dalam memenuhi nutrisinya semua karang dapat menggunakan tentakelnya untuk menangkap mangsa (plankton). Proses penangkapannya 
mempergunakan bantuan nematocyte suatu bentuk protein spesifik yang memiliki kemampuan proteksi dan melumpuhkan biomassa tertentu seperti zooplankton. Meskipun mempunyai kemampuan feeding active, akan tetapi kebanyakan proporsi terbesar makanan karang berasal dari simbiosis yang unik, yaitu zooxanthellae. Zooxanthellae ini merupakan algae uniselluler yang bersifat mikroskopik hidup dalam berbagai jaringan tubuh karang yang transparan dan menghasilkan energi langsung dari cahaya matahari melalui fotosintesis.

Biasanya zooxanthellae ditemukan dalam jumlah yang besar dalam setiap polyp, hidup bersimbiosis dan memberikan warna pada polyp, energi dari fotosintesis dan $90 \%$ kebutuhan karbon polyp (Sebens, 1997). Zooxanthellae menerima nutrisi-nutrisi penting dari karang (polyp) dan memberikan sebanyak $95 \%$ hasil fotosintesisnya (energi dan nutrisi) kepada polyp (Muscatine, 1990). Assosasi yang erat ini sangat efisien, sehingga karang dapat bertahan hidup bahkan di perairan yang sangat miskin hara. Keberhasilan hubungan ini dapat dilihat daribesarnya keragaman dan usia karang yang sangat tua, berevolusi pertama kali lebih dari 200 juta tahun yang lalu (Burke et al. 2002).

Berdasarkan transfer nutrisi ini maka dapat dinyatakan bahwa karang dapat menyediakan nutrisinya baik melalui feeding active dan feeding passive. Feeding active dilakukan dengan menembakkan nematocyte ke arah mangsa dan mentransfernya melalui mulut yang terdapat di bagian atas; sedangkan feeding passive diperoleh melalui transfer hasil fotosintesis zooxanthellae.

Karang mempunyai bentuk rangka untuk menyokong badannya yang sederhana. Karang pembentuk terumbu mempunyai kerangka dari kalsium karbonat yang proses pembentukannya memerlukan waktu lama sebagai hasil dari simbiosisnya dengan zooxanthellae (Goreou, 1961 in Lenhoff dan Muscatine,
1974). Karang ini kebanyakan dari kelompok scleractinia yang dikenal sebagai hermatipik atau pembentuk terumbu. Berdasarkan hal tersebut, maka dapat dinyatakan bahwa simbiosis mempunyai peran penting dalam proses kehidupan karang. Adanya simbiosis, maka secara phototropikal dapat memperpanjang kehidupan karang dalam suatu periode tertentu. Apabila dikaitkan dengan konsep spesiasi binatang karang (Veron, 1995) maka peran aktif simbiosis zooxanthellae dalam jaringan karang dan biogeografinya bersama dengan faktor lingkungan dapat dinyatakan sebagai penggerak dalam proses microevolusi dalam kehidupan karang. Ini dapat dipandang dalam beberapa skala :

1. Dalam skala ekologi : bahwa cahaya bertanggung jawab atas pembatasan kedalaman untuk semua karang dan terumbur karang sehingga secara - prinsipil cahaya merupakan parameter lingkungan yang dapat mengendalikan morfologi serta hubungan intra spesifik yang pada gilirannya dapat menentukan diversitas species;

2. Dalam skala geografis : bahwa ketergantungannya terhadap simbiosis menjadikan karang dengan mudah tumbuh melampaui makroalgae; faktor inilah yang kemungkinan besar menyebabkan terhalangnya karang/ terumbu karang dari pengaruh faktorfaktor fisika lingkungan di lintang tinggi.

3. Dalam skala geologi : bahwa gangguan terhadap simbiosis oleh sebab kekurangan cahaya menjadikan suatu peranan pokok dalam kepunahan massa (yang dibentuk oleh karang dan terumbu karang).

Secara nyata keadaan yang merugikan dari ketergantungan terhadap cahaya timbul karena kebutuhan dari simbiosis alamiah. Sejauh diketahui, hanya sedikit sekali spesies karang dapat eksis secara fakultatif (karang yang dapat hidup untuk jangka waktu tak terbatas dengan atau tanpa adanya zooxanthellae atau yang biasa disebut aposymbiosis), yakni hanya Astrangia 
danae (Jasques, 1983) dan mungkin Madracis sp, nampaknya termasuk dalam kelompok ini. Kemudian memunculkan pertanyaan mengapa terjadi simbiosis fakultatif pada karang?. Hal ini mungkin dapat dterangkan dalam kejadian dua tahap, yaitu pertama adanya hubungan yang sederhana dengan rantai makanan secara fisiologis (kemungkinan masih dapat berharap dari nutrisi eksternal), kedua adanya bentuk simpanan dari dasar genetis tiap jenis karang yang terjadi dari evolusi multispesies yang sinkron dan kemungkinan paralel dengan evolusi metochondria dari protozoa (Burke et al. 2002).

Dengan demikian menjadi jelas bahwa konsep simbiosis menjadi demikian penting dalam kehidupan karang dan kelestarian ekosistem bentukannya. Hubungan intra maupun ekstraspesifik yang terus berlangsung dalam proses pembentukan kestabilan ekosistem terumbu karang secara filosofis termasuk dalam konsep microevolusi yang ditampilkan oleh hubungan simbiosis antara zooxanthellae dan binatang karang.

\section{TERAPAN ENDOSIMBIOSIS BAGI EVALUASI KUALITAS TERUMBU KARANG}

Sebagaimana telah dikemukakan di atas bahwa ancaman terhadap ekosistem terumbu karang terjadi baik secara anthropogenic maupun secara alamiah. Turunan "dari keduanya baik yang bersifat eksploitatif secara langsung maupun tidak langsung adalah adanya penurunan kualitas air laut di wilayah perairan ekosistem terumbu karang. Ini berarti bahwa air merupakan polutan bagi binatang karang. Di laut yang sangat dinamis penyebaran polutan menjadi efektif dengan cakupan wilayah dampak yang luas. Di pihak lain, karang sebagai binatang yang bersifat menetap; oleh adanya sebaran polutan menyebabkan karang sebagai biota dengan potensi kerentanan yang tinggi.

Apabila karang tidak dapat bergerak secara bebas akibat tekanan ling- kungannya, maka beberapa biota penghuni ekosistem bentukannya dapat berpindah ataupun tinggal bergantung kepada jenis biota. Di sini memunculkan pertanyaan, apakah ekosistem terumbu karang dapat pulih kembali?, ini sangat bergantung kepada kemampuan mengendalikan sumber-sumber destruktifnya. Dengan asumsi dapat dikendalikannya faktor polutif/destruktif maka penentu perubahan ekosistem adalah biota karang itu sendiri, meskipun mengalami suksesi yang sangat lama dengan tahap-tahap dominasi oleh Kelompokkelompok lain non karang (Colhan, 1981; Suharsono dan Kiswara, 1984). Ini yang nampaknya menjadi dasar ditentukannya binatang karang sebagai tolok ukur dalam mengevaluasi kondisi ekosistem terumbu karang.

Penggunaan analisis cover life (tutupan karang hidup) dalam kaitan tersebut memang benar. Kriteria yang pada awalnya dimunculkan oleh Gomez et al (1981) adalah :

1. Kategori miskin atau rusak adalah 0$24 \%$

2. Kategori sedang adalah $25-49,9 \%$

3. Kateori baik adalah $50-74,9 \%$ dan

4. Kategori sangat baik (excellent) adalah $75-100 \%$

Namun pada kenyataannya (mengacu kepada fenomena suksesi sebagaimana diinformasikan Colhan (1981) dan Suharsono dan Kiswara (1984) memunculkan beberapa kerancuan :

Pertama, apakah dibenarkan dari sisi ekologis bahwa dominansi menjadi ukuran kestabilan ekosistem;

Kedua, apabila nilai keragaman diperoleh, berapakan nilai nyata sebagai tolok ukur strata kesatuan kategori, mengigat bahwa sifat perkembangan ekosistem terumbu karang mengenal adanya suksesi;

Ketiga, dengan imbangan nematocyt yang berbeda antar biota karang (Lenhoff dan Muscatine, 1974) dapat diabaikan dalam penentuan penguasaan space oleh perkembangan masing-masing koloni karang dan Keempat, dimungkinkan terjadinya sibling species karena kenyataan 
ditemukannya sifat inbreding sehingga akan mengacaukan taksonomi dan perhitungan keragaman.

Dengan adanya faktor-faktor tersebut maka menyebabkan penggunaan analisis tutupan karang hidup perlu diperlengkapi dengan kajian simbiosis.

Peran endosimbiosis saat ini nampaknya menjadi unsur yang sering dipergunakan sebagai tolok ukur bagi penipisan penyebaran karang secara latitude. Dalam hal ini mempergunakan peubah pembatas (limiting factor) yaitu suhu dan cahaya. Oleh Veron (1995) diterangkan bahwa pandangan yang telah bertahan lama dimana saat ini tidak banyak didukung adalah bahwa distribusi terumbu karang dibatasi oleh distribusi karang; dan bahwa hal ini secara umum menyangkut proses fisiologi khususnya dalam hal penangkapan pakan dan reproduksi. Logika alternatifnya adalah bahwa temperatur membatasi keduanya baik terumbu karang dan karang melalui proses interaksi ekologi, dimana kebutuhan energi (cahaya dan hubungan simbiosis) dari terumbu karang secara progresif menjadi kurang kompetitif melawan dominasi makroalgae dalam ekosistem.

Sejak diawali penelitian oleb Dana (1843); Vaughan (1918 dan 1919), Davis (1928) dan Yonge (1940) kemudian berturut-turut Vaughan dan Wells (1943), Wells (1954a dan 1957), Stoddart (1969), Rosen (1971 dan 1984) (kesemuanyaa disitiî dalam Veron, 1995); temperatur $18^{\circ} \mathrm{C}$ yang terus menerus dalam periode waktu tertentu diidentifikasi sebagai temperatur minimum air lauf yang secara fungsional terumbu masih dapat bertahan hidup normal. Korelasi ini diuji ulang dalam cahaya dengan rentang temperatur dan dicatat di Jepang oleh Veron dan Minchin (1992) dan ditemukan benar. Temperatur rendah sering tercatat di lingkungan terumbu karang, tapi dalam sebagian kasus hanya ditemukan adanya kematian parsial (dimana bagian koloni karang mati) atau meliputi terumbu karang yang secara geologis merupakan hasil peninggalan lampau atau secara primer terdiri dari runtuhan yang tidak terkonsulidasi. Fluktuasi temperatur dalam jangka pendek di terumbu karang di Teluk Teluk (Arab dan Parsia) (Coles, 1988; Coles dan Fadlallah, 1991) diketahui sebagai suhu minimum secara global. Dalam hal ini sangat sedikit zooxanthellae diketahui mentolerir temperatur di bawah $11^{\circ} \mathrm{C}$ pada kondisi alamiah.

Stress temperatur panas tidak seperti stress yang dialami oleh karang pada temperatur dingin, yakni bukan merupakan fenomena pembatasan dispersi karang dan juga tidak merupakan pengaruh batas-batas lintang. Secara prinsipil, pengaruh temperatur panas menyebabkan breakdown (kerusakan) simbiosis karang dengan zooxanthellae yang diekspresikan dalam bentuk keluarnya zooxanthellae dari jaringan sel karang atau yang lebih dikenal dengan istilah bleaching. Meskipun stress temperatur tinggi dapat terjadi di daerah terumbu karang lintang tinggi (seperti di Hawaii; Jokiel dan Coles, 1990; di Bermuda, Cook, 1990) itu cenderung terjadi dalam areal yang sempit di kawasan ekuator dimana secara umum ini berkaitan dengan saat surut atau surut yang tidak normal. Pada skala biogeografi, stress temperatur panas selalu berkorelasi dengan fluktuasi cuaca harian yang mana $\mathrm{El}$ Nino Southern Oscillation (ENSO) telah diketahui pengaruhnya sangat penting (Glynn, 1990; Guzman dan Cortes, 1992).

Dari kajian lain seperti dilakukan oleh Suharsono dan Kiswara (1984) bahwa pada saat karang mengalami tekanan ditemukan adanya indikasi pelepasan zooxanthellae. Pada kondisi dilepaskannya zooxanthellae maka akan dapat ditemukan adanya perbedaan signifikan rasio chlorophyl a : chlorophyl c serta adanya sock protein sebagaimana diinformasikan oleh Nganro (1992) pada biota simbion soft coral. Keduanya secara metodologis dapat dilakukan pengukurannya. Di samping itu, proses relokasi zooxanthellae dalam jaringan 
karang akan berbeda pembelahannya (mitotic indeks) pada kondisi alamiah maupun tertekan (Zamani, 1991; Nganro, 1992).

Atas dasar indikasi-indikasi tersebut, maka kiranya kajian tentang endosimbiosis perlu dipertimbangkan sebagai salah satu indikator evaluasi kualitas ekosistem terumbu karang. Dengan mengkorelasikan diantara kajian tutupan karang hidup dan beberapa indeks biologi endosimbiosis dimungkinkan diperoleh kriteria klasifikasi kualitas ekosistem terumbu karang sekaligus sebagai informasi penting dalam menyusun indeks ancaman kualitas ekosistem terumbu karang.

\section{DAFTAR PUSTAKA}

Burke, L., E. Selig and M. Spalding. 2002. Reef at risk in South East Asia. www.wri.org/reefatrisk. Dikunjungi tanggal 2 Maret 2002.

Coles, S.L.1988. Limitation of reef coral development in the Arabian Gulf : temperatur or algal competition. Proc. 6th Int. Coral Reef Symp., Australia.

Coles, S.L. and Fadlallah Y.H. 1991. Reef coral survival dan mortality at low temperatures in arabian Gulf : a new species-specific lower temperature limits. Coral Reefs 9 : 231-7.

Colhan, M.W. 1981. Succession and Recovery of a coral reef after predation by Acanthaster planci (L). Proc. 4th Int. Coral Reef Symp., Philippines.

Cook, C.B., 1990. Elevated temperaturs and bleaching on a high latitude coral reef : the 1988 Bermuda event. Coral reefs $9 ; 45-9$

COREMAP. 2001. Kebijakan nasional pengelolaan terumbu karang di Indonesia. Coral Reef Rehabilitation and Management Program, Jakarta.
Glynn, P.W. 1990. Global ecological consequences of the 1982-1983 El Nino southern oscillation. Elsevier Oceanography Series 52.

Gomez, E.D., A.C. Alcala and A.C. San Diego. 1981. Status of Philippine coral reefs. Proc. 4th Int. Coral Reef Symp., Philippines.

Guzman, H.M. and J. Cortes, 1992 Coral reef community structure at Cano Island, Pacific CostanRica. Mar. Ecol. 10 : 23-41.

Jasques, T.G. 1983. Experimental ecology of the temperate schleractinia coral Astrangia danae. II. Effect of temperature, light intensity and symbiosis with zooxanthellae on metabolic rate and calcification. Mar. Biol. 76 : 135-48.

Jokiel, P.L.J and S.L. Coles, 1990. Response of Hawaiian and other Indo-Pacific reef corals to elevated temperaturs. Coral Reefs 8 : 15562.

Lenhoff, H.M and L. Muscatine, 1974. Coelenterate biology : Review and new perspective. Academic Press. London.

Moosa, M dan Suharsono. 1995. Rehabilitasi dan pengelolaan terumbu karang: suatu usaha menuju ke arah pemanfaatan sumberdaya terumbu karang secara lestari. Pros. Seminar Nasional Pengelolaan Terumbu Karang, Jakarta 10-12 Oktober 1995: 189200

Muscatine, L.1990. The role of symbiotic algae in carbon and energy flux in reef coral. In. Dubinsky Z. (Ed). Coral Reefs, ecosystem in the world. Elsevier. Amsterdam.

Nganro, N.R. 1992. Development of a tropical marine water quality bioassay using symbiotic coelenterata. Ph.D. Thesis, the Univ. of Newcastle upon tyne, UK., $225 p$. 
Perez, J.M., 1982. Structure and dynamics of assemblages in the pelagial. Ed. By O. Kinne. In Marine Ecology : A comprehensive, integrated tretise on life in oceans and coastal waters Vol. 1. John Wiley \& Sons, Ltd. New York.

Sebens, K.P.1987. Coelenterata. In T.J. Pandian and F.J. Vernberg (eds). Animal energetics. Academic Press, San Diego California.

Suharsono dan W. Kiswara. 1984. Kematian alami karang di Laut Jawa. Oseana, X:31-40.

Veron, J. E. N. 1995. Coral in space and time. Australian Institute of Marine Science Cape Ferguson, Townsville, Quensland.
Veron, J.E.N and P.R. Minchin. 1992. Correlation between sea surface temperature, circulation patterns and the distribution of hermatypic corals of Japan. Continental Self Res. 12 : 835-57.

Westmacott, S., K. Teleki., Wells, S. and J. West. 2000. Pengelolaan terumbu karang yang telah memutih dan rusak. IUCN, Switzerland and Cambridge.

Zamani, N.P. 1991. The use and measurement of mitotic index of zooxanthellae as a bioassay tools. M.Sc. thesis in tropical coastal management. The Univ. Newcastle Upon Tyne, UK., 49 p.. 